\title{
Plant-parasitic nematodes on turfgrass in Queensland, Australia, and biosecurity issues associated with the interstate transfer and eradication of southern sting nematode (Ibipora lolii)
}

\author{
G. R. Stirling' ${ }^{1} \cdot$ A. M. Stirling ${ }^{1} \cdot$ L. Eden ${ }^{2}$
}

Received: 7 July 2021 / Accepted: 31 August 2021 / Published online: 30 September 2021

(c) Australasian Plant Pathology Society Inc. 2021

\begin{abstract}
Southern sting nematode (Ibipora lolii), by far the most damaging nematode pest of turfgrass in Australia, was first reported from the Newcastle area of New South Wales in 1979 and is now widely distributed in the Central Coast region of NSW; is causing severe damage to sportsgrounds in Perth, Western Australia; and has been reported from a few locations in other states. This paper reports a recent example of interstate transfer, as small rolls of turf transferred from a turf nursery in Victoria to the Brisbane Cricket Ground (the Gabba) for the Australian Football League Grand Final in October 2020 were found to be infested with I. lolii. Despite this transfer, evidence is provided to suggest that Queensland should be considered provisionally free of I. lolii. First, in the period from 2006 to 2021, 744 turfgrass samples from 160 Queensland locations were processed by two diagnostic laboratories and I. lolii was never detected. Second, I. lolii was not found at the two Queensland locations reported in 2010 as being infested. Third, an action plan designed to eliminate I. lolii from the Gabba (removal and disposal of the infested turf; fumigation of the sites where the infested turf had been laid; and application of nematicides to the fumigated areas and the whole oval) appears to have been successful, as I. lolii was not detected in a post-treatment monitoring program. The paper concludes by arguing that Queensland biosecurity authorities should list $I$. lolii as one of its priority pests, establish a surveillance program for the nematode, and develop strategies to minimise the risk of I. lolii being transferred into and within the state.
\end{abstract}

Keywords Ibipora lolii $\cdot$ Southern sting nematode $\cdot$ Biosecurity $\cdot$ Turf $\cdot$ Sports fields $\cdot$ Soil fumigation

\section{Introduction}

Plant-parasitic nematodes are serious pests of turfgrass because the damage they cause during the feeding process restricts root development and increases the susceptibility of roots to other soilborne pathogens (Smiley et al. 2005). Sedentary endoparasites, migratory endoparasites and ectoparasites all have the potential to cause aboveground symptoms, which are usually manifested as reduced vigour, slow growth, chlorosis, and susceptibility to environmental stress. Details of these pests, and the management practices

G. R. Stirling

graham.stirling@biolcrop.com.au

1 Biological Crop Protection, 3601 Moggill Road, Moggill, QLD 4070, Australia

2 Eden Diagnostic Services, 9 Tatong Street, Indooroopilly, QLD 4068, Australia which can be used to keep them under control, can be found in a wide range of extension publications, including Stirling (2008), Buckley et al. (2010) and Crow (2014, 2017).

Many scientific papers list the plant-parasitic nematodes associated with turfgrass in various countries (see Zeng et al. 2012 for examples) and in some cases, the morphologicalbased identification used in early studies has been confirmed using molecular methods (Zeng et al. 2015). However, there have been no comprehensive surveys to categorise the plantparasitic nematodes associated with turfgrass in Australia. Couch (Cynodon dactylon), hybrid couch (C. dactylon x $C$. transvaalensis), kikuyu (Pennisetum clandestinum), buffalo (Stenotaphrum secundatum), bent (Agrostis stolonifera), tall fescue (Festuca arundinacea) and perennial rye (Lolium perenne) are the most widely grown turf species and 23 nematode genera are known to be associated with these grasses (McLeod et al. 1994), while Nambiar and Quader (2008) indicated that 13 genera had been detected on golf courses and bowling greens. To improve our knowledge in this area, 
our first objective was to provide more detailed information on the occurrence of plant-parasitic nematodes on turfgrass in Queensland, the second-largest Australian state.

The remainder of the paper is focused on southern sting nematode (Ibipora lolii), as it is by far the most destructive nematode pest of turfgrasses in Australia. Wilting, yellowing, patchiness, and an inability to recover from stress are common above-ground symptoms, while below-ground, roots damaged by I. lolii are short and stunted. Root biomass is often markedly reduced when low numbers of the nematode are present (Stirling et al. 2013; Ruscoe and Stirling 2020; Ruscoe et al. 2021). In contrast, other plant-parasitic nematodes have higher damage thresholds (Stirling 2008) and only cause significant damage at much higher population densities.

When I. lolii was described by Siviour and McLeod (1979), the authors indicated that the nematode was widespread on bowling greens, golf tees and putting greens in the Newcastle area of New South Wales (NSW). Poor growth symptoms were observed on bent, couch and perennial ryegrass, with greenhouse tests showing that the nematode was highly pathogenic to the latter two grasses. The infested area in NSW is still centred on Newcastle but has grown much larger in the last 40 years, as I. lolii is commonly found in diagnostic samples from a coastal region that is about $500 \mathrm{~km}$ long and extends from Coffs Harbour in the north to Sydney in the south (Stirling et al. 2013).

The Perth region of Western Australia (WA) is the only other area where I. lolii is widely distributed. In the late 1970s, a new variety of couch grass developed in Newcastle was taken to WA and widely planted on bowling greens. Circumstantial evidence suggests that the turf was infested with I. lolii because in the mid-1980s, many bowling clubs were having problems with their greens and the nematicide fenamiphos was being applied to reduce the damage caused by the nematode (Stirling et al. 2013). Since then, the area infested with I. lolii in WA has continued to expand because many turf farms were infested. The nematode is widespread on sports fields, golf courses and other recreational areas and is causing major problems for suburban councils and turfgrass managers. A recent survey showed that I. lolii is now present in $51 \%$ of municipal sports fields in the Perth metropolitan area (Ruscoe et al. 2021).

There have been no systematic surveys to assess the distribution of I. lolii in other states. However, Nambiar et al. (2010) indicated that Morulaimus gigas (syn. I. lolii) was present at several locations in Victoria, and since then one additional infestation has been identified in diagnostic samples (GR Stirling, unpublished). Nambiar et al. (2010) also reported that the nematode was present in South Australia and Queensland. The infested sites Queensland sites were not identified, but when the authors were contacted, they indicated that one was in Brisbane (Indooroopilly Golf Club) and the other in north Queensland (Weipa Bowls Club). Thus, a second objective of this work was to check whether I. lolii was still present at those locations.

The results of work reported later in this paper cast doubt on whether I. lolii is present in Queensland, and so the final component of the paper focuses on the first known transfer of the nematode into Queensland. In October 2020, small patches of turf were brought from Victoria and laid at the Brisbane Cricket Ground, one of the main sports stadiums in Brisbane and generally known as the Gabba. Evidence is presented to show that I. lolii was not present at the Gabba prior to the transfer, but that the turf from Victoria was infested. Although it is usually impossible to eliminate a plant-parasitic nematode once it is introduced to a new area, it was felt that it might be possible in this case, as the infested turf had only been laid in a very small area. Thus, an attempt was made to eliminate the nematode and the paper finishes by providing details of the eradication program that was implemented and the results obtained.

\section{Materials and methods}

Nematodes were retrieved from turfgrass samples using a modified version of an extraction method developed by Whitehead and Hemming (1965) that is commonly referred to as the Baermann tray technique. Samples consisting of multiple cores of turf were gently mixed to break the cores apart and a $200 \mathrm{~mL}$ sub-sample of soil and roots was spread on a tissue-covered mesh basket. The basket was then placed in a tray and water was added to saturate the soil. After incubation for two days at $24-28{ }^{\circ} \mathrm{C}$, nematodes were retrieved by sieving the nematode suspension twice on a $38 \mu \mathrm{m}$-aperture sieve. Plant-parasitic nematodes were identified and counted under a compound microscope at a magnification of 40X. As samples were obtained from a variety of locations, they were processed in an extraction facility that was designed to prevent the spread of nematodes that are not widely distributed. Wastewater and any nematodes it contained was retained in an overflow tank, while soil that may have been infested with I. lolii, together with the plastic bags and containers in which it had been transported, was autoclaved prior to disposal.

\section{Plant-parasitic nematodes on turfgrass in Queensland}

During the 15 years from 2006 to 2020, Biological Crop Protection provided a nematode diagnostic service for the turf industry in Australia. Thousands of samples were received and they generally consisted of multiple soil cores collected to a depth of about $10 \mathrm{~cm}$. Samples were taken by superintendents, turfgrass managers or consultants as part 
of routine nematode monitoring programs, or because plantparasitic nematodes were suspected to be causing decline or poor growth problems. Nematodes were extracted from $200 \mathrm{~mL}$ sub-samples using the Baermann tray technique and clients were then sent a written report containing the nematode counts, together with an interpretation of the results.

A total of 435 diagnostic samples were received from Queensland and they came from 123 locations, with the number of locations in various regions of the state as follows: greater Brisbane (44), the Gold Coast (20), Sunshine Coast and hinterland (19), north Queensland (16), Wide Bay and Burnett (10), central Queensland (8), and the Darling Downs and south west Queensland (6). More than half the samples were from golf courses (53\%), with the remainder from bowling greens (20\%), sports fields (11\%), racetracks (9\%), turf farms (4\%) and other uses (3\%). Golf greens were generally planted to hybrid couch and bowling greens to couch or hybrid couch, while couch and kikuyu were the main grasses on the sports fields and racetracks. The results from these samples were collated to provide an indication of the nematode genera present, their population densities, and their occurrence in various climatic zones and usage situations.

In April 2015, the third author established another nematode diagnostic service for the turf industry (Eden Diagnostic Services) and in the six years to April 2021, processed 309 samples from 60 locations in Queensland. These samples were also processed using Baermann trays and the results were collated as described in the previous paragraph.

\section{Assessment of sites previously reported to be infested with Ibipora Iolii}

The first Queensland site previously reported to be infested with I. lolii was the Indooroopilly Golf Club, a course located about $10 \mathrm{~km}$ southwest of the Brisbane CBD. On 1 September 2000, a sample from the third green had been sent via the Australian Golf Course Superintendents Association (AGSCA) and processed in Victoria. The results forwarded to the Golf Club indicated that the sample contained 78 I. lolii/ $200 \mathrm{~mL}$ soil. On 16 October 2014, a sampling tube $22 \mathrm{~mm}$ in diameter was used to collect approximately 60 soil cores (about $4 \mathrm{~kg}$ of soil) from the same green. The sample was mixed carefully and nematodes were extracted from ten $200 \mathrm{~mL}$ sub-samples using Baermann trays. The following year (11 June 2015) 12-core samples were collected from another six greens on the course and $200 \mathrm{~mL}$ sub-samples processed in the same way.

The second site where the co-authors of Nambiar et al. (2010) indicated that I. lolii had been detected was Weipa Bowls Club in far north Queensland. In this case, samples were submitted by a consultant on 11 October 2000 and results from the Victorian Department of Primary Industries indicated that 24 and 18 I. lolii had been detected in greens 1 and 2, respectively. In November 2014, the club manager forwarded samples from both greens and they were processed using the method described previously.

Nambiar et al. (2010) prepared permanent slides of the I. lolii obtained from both sites and deposited them in the Victorian Plant Pathology Herbarium (VPRI). Those slides (VPRI voucher numbers 34290 and 34291 from Indooroopilly Golf Club and 34292 and 34310 from Weipa Bowls club) were obtained from the herbarium so that the identity of the nematodes could be confirmed.

\section{Plant-parasitic nematodes at the Gabba and the transfer of I. Iolii from Victoria}

The Melbourne Cricket Ground (the MCG) has a total seating capacity of 100,024, making it Australia's largest sporting stadium. On 4 April 2017, two diagnostic samples from the MCG (labelled 'Old Corridor' and 'New Turf') were received by the third author and both contained low numbers of I. lolii ( 3 and 5 nematodes/200 $\mathrm{mL}$ soil respectively). The following year (27 March 2018), a third sample was received from the MCG and it was also infested with I. lolii (8 nematodes $/ 200 \mathrm{~mL}$ soil).

The Grand Final of the Australian Football League (AFL) is normally played at the MCG, but because of quarantine restrictions due to the Covid-19 pandemic, the 2020 final was played at the Gabba. However, prior to the final, a decision was made to transfer some MCG turf to the Gabba so that players could step onto some of its 'hallowed turf' as they ran onto the ground. Thus, rolls of turf about $3 \mathrm{~m}$ long and $1 \mathrm{~m}$ wide that had been taken from the MCG turf nursery were placed between the boundary line and the fence at each of the three entrances used by players at the Gabba. Each piece consisted of a roll of Hero Hybrid Grass ${ }^{\mathrm{TM}}$, a combination of artificial grass fibres and natural grass on a reticulated plastic grid.

As the authors of this paper knew that the MCG was infested with I. lolii, there was clearly a risk that the nematode would be transferred to the Gabba. Consequently, on the day after the Grand Final (25 October 2020), two sets of samples were collected: the first to check whether I. lolii was present at the Gabba and the second to determine whether the nematode could be detected in the turf that had come from the MCG. The sample from the playing surface consisted of 30 cores $22 \mathrm{~mm}$ in diameter and $15 \mathrm{~cm}$ long that were collected from random positions across the oval. The soil was thoroughly mixed and nematodes were extracted from two $200 \mathrm{~mL}$ sub-samples.

Each of the three player entrances was sampled on the same day, with secateurs being used to remove six cuboids of turf about $10 \times 10 \times 6 \mathrm{~cm}$ in size from each location (Fig. 1). Some hybrid turf rolls had not been laid on the 
Fig. 1 An example of the cuboid samples collected from turf rolls transported from the MCG to the Gabba, and the reticulated plastic grid under each roll
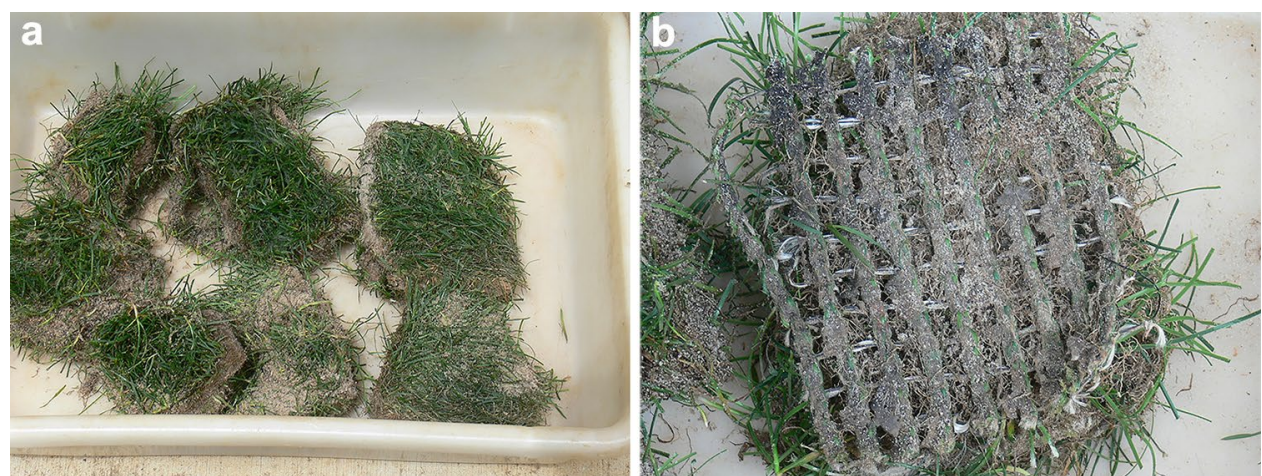

oval, and as they had been stored under the stadium in an area that was used by grounds staff, they were sampled in the same way. The presence of the reticulated grid made it difficult to obtain a representative sample of the soil from each site. Nonetheless, the cuboids were cut with secateurs and about $1 \mathrm{~kg}$ of soil, sand and roots was retrieved from each of the four sites, with nematodes then being extracted from $200 \mathrm{~mL}$ sub-samples.

As results from the above samples indicated that I. lolii was present in the imported turf, further samples were collected four days later to check whether the nematode had moved onto the oval or was present under the rolls of turf that had been laid on the oval. A $22 \mathrm{~mm}$ diameter sampling tool was used to collect these samples, with the turf growing within in $1 \mathrm{~m}$ of the imported turf being sampled to a depth of $15 \mathrm{~cm}$. The imported turf was then lifted and the area under it was sampled. In both cases, 20 cores were collected from each of the six sampling sites.

To obtain more detailed information on the nematode status of the Gabba, a monitoring program was established to assess nematode populations every $6-8$ weeks. The sampling protocol involved sub-dividing the oval into four sections (north-west, north-east, south-east, and southwest) and then using a $22 \mathrm{~mm}$ diameter sampling tube to collect 20 soil cores about $15 \mathrm{~cm}$ long from each section. The first set of samples was collected on 29 October 2020 and further samples were collected in the same way on 10 December 2020 and 4 February, 29 March, and 31 May 2021. At each sampling time, nematodes were extracted from $200 \mathrm{~mL}$ sub-samples.

During the monitoring period, there were changes in the dominant grass at the Gabba. Perennial rye (Lolium perenne) and couch (Cynodon dactylon $\mathrm{cv}$. Legend) were both present when the first sample was taken but two selective herbicides (Tribute ${ }^{\mathrm{TM}}, 22.5 \mathrm{~g} / \mathrm{L}$ foramsulfuron at $1.5 \mathrm{~L} / \mathrm{ha}$ and Destiny ${ }^{\mathrm{TM}}, 100 \mathrm{~g} / \mathrm{kg}$ iodosulfuron-methyl-sodium at $25 \mathrm{~g} / \mathrm{ha}$ ) were applied to the oval on 30 October 2020, and so the couch became predominant during summer. The oval was re-seeded with perennial rye on 20 April 2021, which meant that both grasses were again present when the last sample was taken.

\section{Action plan to eliminate I. Iolii from the Gabba}

Once it was clear that the turf transported from Victoria was infested with I. lolii, an action plan was developed to eliminate the nematode from the Gabba. This plan had four components: removal and disposal of the infested turf; fumigation of the sites where the infested turf had been laid; application of nematicides to the fumigated areas and the whole oval; and a nematode monitoring program to assess the effectiveness of the eradication program.

On 30 October 2020, about three weeks after the infested turf had been brought to the Gabba, the hybrid grass turf that had been planted on the oval or stored under the stadium was placed in waste disposal bins, taken to a Resource Recovery Centre operated by Brisbane City Council, and placed with general waste that was destined for landfill. A layer of soil below the infested turf and all the turf within a metre of it was also removed and disposed of in the same way. During this process, care was taken to ensure that no soil was misplaced and that the oval was not contaminated by infested soil as it was being removed.

The three areas from which turf and soil had been removed were about $5 \mathrm{~m}$ long and $3 \mathrm{~m}$ wide, and they were cordoned off to prevent access by ground staff and visitors. Then, on 20 November 2020, granules of Basamid (940 g/ $\mathrm{kg}$ dazomet) were spread on the soil surface at a rate of $70 \mathrm{~g} / \mathrm{m}^{2}$ and incorporated into the soil to a depth of $10 \mathrm{~cm}$. Each of the treated areas was immediately irrigated with about $6 \mathrm{~mm}$ of water and then covered with $200 \mu \mathrm{m}$ thick plastic sheeting and sand to minimise loss of the fumigant. On 4 December 2020, the plastic cover was removed and soil samples ( 20 cores at depths of $0-10 \mathrm{~cm}$ and $10-30 \mathrm{~cm}$ ) were collected from each treated area to check that the fumigant had been effective. Five days later, a layer of sand about $5 \mathrm{~cm}$ deep was added to the fumigated areas and each area 
was then replanted with Legend couch obtained from a local turf farm.

The nematicide program commenced on 24 December 2020 when Agador ( $20 \mathrm{~g} / \mathrm{L}$ abamectin) was applied to the whole oval at a rate of $2 \mathrm{~L} / \mathrm{ha}$. A boom spray $6 \mathrm{~m}$ wide was used to apply the nematicide with about $440 \mathrm{~L}$ water/ha, and the chemical was washed into the soil with $6 \mathrm{~mm}$ of irrigation water. Further applications were done in the same way on 8 and 22 January 2021. A second nematicide (Indemnify, $400 \mathrm{~g} / \mathrm{L}$ fluopyram) was applied in the same way at $1.25 \mathrm{~L} / \mathrm{ha}$ on 28 January 2021, with a follow-up application at the same rate on 27 February. On 4 February, 29 March and 31 May 2021, soil cores to a depth of $15 \mathrm{~cm}$ were collected from the three areas where infested turf had been laid, together with the four sections of the oval that were being regularly sampled in the monitoring program.

\section{Results}

\section{Plant-parasitic nematodes on turfgrass in Queensland}

The plant-parasitic nematodes found in 435 diagnostic samples processed by Biological Crop Protection are listed in Table 1. Rotylenchus brevicaudatus occurred at relatively high population densities in many samples and another spiral nematode (Helicotylenchus dihystera) was also relatively common. Both nematodes were often present in the same samples. Other plant parasites found at $23 \%$ or more of the locations were stubby root nematode (predominantly
Paratrichodorus minor), ring nematode (unidentified nematodes in the family Criconematidae) and various nematodes identified to genus level: sheath (Hemicycliophora), dagger (Xiphinema), root-lesion (Pratylenchus) and root-knot (Meloidogyne). However, their population densities were generally well below the damage threshold for each genus. Five other genera were observed occasionally and southern sting nematode (I. lolii) was never detected.

The results showed that golf courses, bowling greens and sports fields generally had a similar range of plant-parasitic nematodes. However, racetracks were quite different, as Meloidogyne, Pratylenchus and Tylenchorhynchus were much more common, being detected in 56, 55 and $13 \%$ of the samples, respectively. The five turf farms from which samples were obtained also stood out as being different, as relatively few genera were detected and counts were generally very low $(<30$ plant-parasitic nematodes $/ 200 \mathrm{~mL}$ soil). Another interesting finding was that needle nematode (Paralongidorus) was only detected at coastal locations in the tropics, from Rockhampton to Cairns.

The samples processed by Eden Diagnostic Services were not representative of the Queensland turf industry, as $41 \%$ of the samples came from three locations (two racetracks and one golf course). Nevertheless, the results were much the same as those summarised in Table 1. A similar range of plant-parasitic nematodes were recovered, with the most commonly detected genera being Paratrichodorus, Rotylenchus and Helicotylenchus. Interestingly, the Bermuda 328 couch grass greens on a golf course at the Gold Coast were heavily infested with Xiphinema, as 18 of 39 samples had populations $>1800$ nematodes $/ 200 \mathrm{~mL}$ soil, with the highest
Table.1 Plant-parasitic nematodes detected on turfgrass by Biological Crop Protection in the 15 years from 2006 to 2020 in 435 diagnostic samples from 123 locations in Queensland

\begin{tabular}{lllllll}
\hline Common name & Genus/Family & $\begin{array}{l}\text { \% locations } \\
\text { infested }\end{array}$ & & $\begin{array}{l}\text { Nematodes/200 mL } \\
\text { soil }\end{array}$ & $\begin{array}{l}\text { Damage } \\
\text { threshold }{ }^{\mathrm{b}}\end{array}$ & $\begin{array}{l}\text { \% samples } \\
\text { > Damage } \\
\text { threshold }\end{array}$ \\
\cline { 4 - 5 } & & & Mean ${ }^{\mathrm{a}}$ & Highest & \\
Spiral & Rotylenchus & 49 & 606 & 17,250 & 800 & 3.4 \\
Spiral & Helicotylenchus & 37 & 229 & 2,600 & 800 & 8.3 \\
Stubby root & Paratrichodorus & 63 & 60 & 1,750 & 80 & 10.6 \\
Ring & Criconematidae & 30 & 81 & 1,250 & 300 & 1.8 \\
Sheath & Hemicycliophora & 33 & 65 & 960 & 160 & 3.4 \\
Lesion & Pratylenchus & 29 & 151 & 3,275 & 200 & 4.8 \\
Root-knot & Meloidogyne & 23 & 106 & 1,810 & 800 & 0.5 \\
Dagger & Xiphinema & 25 & 69 & 1,810 & 40 & 6.7 \\
Stunt & Tylenchorhynchus & 4 & 69 & 450 & 400 & 0.2 \\
Cyst & Heterodera & 4 & 20 & 64 & 150 & 0 \\
Needle & Paralongidorus & 3 & 28 & 99 & 20 & 1.4 \\
Reniform & Rotylenchulus & 1 & 109 & 175 & 600 & 0 \\
Pin & Paratylenchus & 0.5 & 67 & 94 & 200 & 0 \\
\hline
\end{tabular}

${ }^{a}$ Mean of samples in which the nematode was detected

${ }^{\mathrm{b}}$ Threshold levels (nematodes/200 mL soil) from Stirling (2008) 
Table.2 Nematodes extracted on 25 October 2020 from hybrid grass rolls that came from the MCG turf farm and were transported to Brisbane and either stored in the grounds shed under the stadium or laid in three player entrances at the Gabba

\begin{tabular}{|c|c|c|c|c|c|}
\hline \multirow[t]{3}{*}{ Location } & \multirow{3}{*}{$\begin{array}{l}\text { Sample } \\
\text { no. }\end{array}$} & \multicolumn{4}{|c|}{ No. nematodes/200 mL soil } \\
\hline & & Sting & Spiral & Stubby root & Free-living \\
\hline & & Ibipora lolii & $\begin{array}{l}\text { Helicotylenchus } \\
\text { dihystera }\end{array}$ & Paratrichodorus sp. & \\
\hline Under stadium & 1 & 0 & 0 & 4 & 3424 \\
\hline Under stadium & 2 & 0 & 2 & 2 & 7504 \\
\hline Under stadium & 3 & 1 & 0 & 8 & 5990 \\
\hline Under stadium & 4 & 1 & 0 & 16 & 4602 \\
\hline Entrance 1 & 1 & 15 & 0 & 18 & 4690 \\
\hline Entrance 2 & 1 & 2 & 0 & 1 & 2185 \\
\hline Entrance 3 & 1 & 0 & 0 & 2 & 1805 \\
\hline
\end{tabular}

count being 3450 nematodes/200 mL soil. In total, 309 samples were processed by Eden Diagnostic Services and I. lolii was not detected. As many of those samples were from 37 locations that had never been checked by Biological Crop Protection, this meant that 744 samples from 160 Queensland locations were processed by the two diagnostic services and I. lolii was never detected.

\section{Assessment of sites previously reported to be infested with I. Iolii}

Five plant-parasitic nematodes were extracted from the third green at Indooroopilly Golf Club: Helicotylenchus, Xiphinema, Heterodera, Paratrichodorus, and a ring nematode in the family Criconematidae. Average numbers in the ten samples processed were 461, 87, 40, 11 and 7 nematodes/200 mL soil, respectively. The same genera, together with Pratylenchus and Hemicycliophora, were found on the six greens sampled in June 2016.

The greens at Weipa Bowls Club had low numbers of Pratylenchus, Xiphinema and an unidentified ring nematode.
The most numerous plant-parasite was a species of Carphodorus, which was found in greens 1 and 2 at densities of 46 and 22 nematodes $/ 200 \mathrm{~mL}$ soil, respectively.

Ibipora lolii was not detected in any of the samples from either Indooroopilly or Weipa. Nevertheless, when the permanent slides deposited in the Victorian Plant Pathology Herbarium by Nambiar et al. (2010) were examined, I. lolii was confirmed as being present on slides from both locations.

\section{Plant-parasitic nematodes at the Gabba and the transfer of I. Iolii from Victoria}

On 25 October 2020, I. lolii was detected in the turf that had been brought to the Gabba from the MCG turf farm. The nematode was found in two of the four samples taken from turf that had been stored under the stadium and was also found in two of the three rolls of turf that had been laid near the boundary line (Table 2). Ibipora lolii was not detected in soil samples collected on the same day from the playing surface of the Gabba.

Table.3 Plant-parasitic and free-living nematodes (FLN) detected in soil samples collected from near and under three player entrances at the Gabba on 29 October 2020, about 3 weeks after imported turf from Melbourne had been laid at each of the entrances

\begin{tabular}{|c|c|c|c|c|c|c|c|c|}
\hline \multirow[t]{3}{*}{ Entrance $^{a}$} & \multicolumn{8}{|c|}{ No. nematodes/200 mL soil } \\
\hline & Sting & Spiral & Spiral & Stubby root & Dagger & Ring & Sheath & FLN \\
\hline & $\begin{array}{l}\text { Ibipora } \\
\text { lolii }\end{array}$ & $\begin{array}{l}\text { Helicotylenchus } \\
\text { dihystera }\end{array}$ & $\begin{array}{l}\text { Rotylenchus } \\
\quad \text { brevicaudatus }\end{array}$ & $\begin{array}{l}\text { Paratrichodorus } \\
\text { teres }\end{array}$ & $\begin{array}{l}\text { Xiphinema } \\
\text { elongatum }\end{array}$ & $\begin{array}{l}\text { Mesocriconema } \\
\text { xenoplax }\end{array}$ & $\begin{array}{l}\text { Hemicycliophora } \\
\text { sp. }\end{array}$ & \\
\hline Near 1 & 0 & 25 & 3 & 28 & 0 & 6 & 1 & 706 \\
\hline Near 2 & 0 & 76 & 0 & 3 & 1 & 0 & 0 & 1360 \\
\hline Near 3 & 0 & 7 & 3 & 14 & 0 & 0 & 0 & 2150 \\
\hline Under 1 & 1 & 18 & 0 & 12 & 0 & 6 & 4 & 640 \\
\hline Under 2 & 0 & 25 & 0 & 10 & 7 & 2 & 0 & 1170 \\
\hline Under 3 & 11 & 0 & 2 & 7 & 0 & 0 & 0 & 1060 \\
\hline
\end{tabular}

${ }^{\mathrm{a}} 1,2$ and 3 refer to the three player entrances where imported turf was laid 
Table.4 Plant-parasitic and free-living nematodes (FLN) detected in soil samples collected from four sections of the playing surface at the Gabba on 29 October 2020

\begin{tabular}{lllllll}
\hline Section & \multicolumn{6}{c}{ No. nematodes/200 mL soil } \\
\hline & Spiral & Spiral & Stubby root & Dagger & Ring & FLN \\
\cline { 2 - 7 } & $\begin{array}{c}\text { Helicotylenchus } \\
\text { dihystera }\end{array}$ & $\begin{array}{c}\text { Rotylenchus } \\
\text { brevicaudatus }\end{array}$ & $\begin{array}{c}\text { Paratrichodorus } \\
\text { teres }\end{array}$ & $\begin{array}{c}\text { Xiphinema } \\
\text { elongatum }\end{array}$ & $\begin{array}{c}\text { Mesocriconema } \\
\text { xenoplax }\end{array}$ \\
\hline North-west & 525 & 127 & 139 & 19 & 0 & 2860 \\
North-east & 212 & 88 & 56 & 14 & 11 & 4660 \\
South-east & 208 & 84 & 36 & 24 & 1 & 2280 \\
South-west & 508 & 80 & 148 & 29 & 5 & 3160 \\
\hline
\end{tabular}

When areas of the oval that were within $1 \mathrm{~m}$ of the imported turf were sampled on 29 October 2020, I. lolii was not detected at the three sites adjacent to where the imported turf had been laid. Six other plant-parasitic nematodes were detected, but their numbers were relatively low (Table 3). A similar range of nematodes was detected in the soil under the imported turf, but one difference was that I. lolii was found at two of the three sites. The highest population was detected under entrance 3 (Table 3), and based on the size of the nematodes, most of them were second and third stage juveniles. Permanent slides of the I. lolii extracted from the turf imported from Victoria were prepared and were later deposited in the nematode collection at the Queensland Museum (Registration numbers G239136, G239137 and G239138).

Results of samples collected from four sections of the Gabba on 29 October 2020 showed that the nematode community was dominated by free-living nematodes. More than $90 \%$ of these nematodes were bacterivores, with the remainder being fungivores (Order Aphelenchida), omnivores (Order Dorylaimida) and predators (family Mononchidae). Five plant-parasitic nematodes were detected, with two species of spiral nematode (Helicotylenchus dihystera and Rotylenchus brevicaudatus) and stubby root nematode (Paratrichodorus teres) being present in relatively high numbers (Table 4). Ibipora lolii was not detected in any of the samples.

\section{Action plan to eliminate I. Iolii from the Gabba}

Results from samples collected 14 days after Basamid had been applied to the areas where infested turf had been laid showed that the fumigant had been effective. Twelve $200 \mathrm{~mL}$ samples were processed ( 2 samples from each of 3 locations and 2 depths) and no free-living or plant-parasitic nematodes were recovered, indicating that the fumigant had killed all the nematodes in the soil to a depth of at least $30 \mathrm{~cm}$. Follow-on samples collected from the fumigated areas on 4 February, 29 March and 31 May 2021 showed that the plant-parasitic and free-living nematodes normally found at the Gabba were present (data not shown), but I. lolii was not detected.

In the 7 months from late October 2020, a total of 20 samples ( 5 sampling times $\times 4$ locations) were processed in the monitoring program at the Gabba and I. lolii was not detected. However, the results suggested that the nematicides applied to the oval had little impact on the plant-parasitic nematodes that were present. Nematode numbers in February, March and May 2021 were not markedly lower than

Table.5 Numbers (mean \pm SE) of plant-parasitic and free-living nematodes (FLN) detected in soil samples collected at regular intervals from four sections of the Gabba before and after nematicides were applied to the oval ${ }^{\text {a }}$

\begin{tabular}{|c|c|c|c|c|c|c|c|}
\hline \multirow[t]{3}{*}{ Sampling time } & \multicolumn{7}{|c|}{ No. nematodes $/ 200 \mathrm{~mL}$ soil } \\
\hline & Spiral & Spiral & Stubby root & Dagger & Ring & Sheath & FLN \\
\hline & $\begin{array}{l}\text { Helicotylenchus } \\
\text { dihystera }\end{array}$ & $\begin{array}{l}\text { Rotylenchus } \\
\text { brevicaudatus }\end{array}$ & $\begin{array}{l}\text { Paratrichodorus } \\
\text { teres }\end{array}$ & $\begin{array}{l}\text { Xiphinema } \\
\text { elongatum }\end{array}$ & $\begin{array}{l}\text { Mesocriconema } \\
\text { xenoplax }\end{array}$ & $\begin{array}{l}\text { Hemicycliophora } \\
\text { sp. }\end{array}$ & \\
\hline 29 Oct. 2020 & $363 \pm 89$ & $95 \pm 11$ & $95 \pm 28$ & $22 \pm 3$ & $4 \pm 2$ & 0 & $3240 \pm 507$ \\
\hline 10 Dec. 2020 & $259 \pm 77$ & $63 \pm 6$ & $63 \pm 60$ & $10 \pm 4$ & 0 & 0 & $1989 \pm 219$ \\
\hline 4 Feb. 2021 & $583 \pm 139$ & $81 \pm 32$ & $81 \pm 25$ & $14 \pm 7$ & $3 \pm 3$ & $6 \pm 6$ & $836 \pm 142$ \\
\hline 29 Mar 2021 & $570 \pm 103$ & $28 \pm 13$ & $28 \pm 18$ & $6 \pm 6$ & $2 \pm 2$ & $1 \pm 1$ & $847 \pm 33$ \\
\hline 31 May 2021 & $318 \pm 78$ & $27 \pm 8$ & $200 \pm 52$ & $9 \pm 1$ & 0 & 0 & $1587 \pm 123$ \\
\hline
\end{tabular}

${ }^{\text {a }}$ The nematicide program commenced on 24 December 2020 and was completed on 26 February 2021 
at the two sampling times prior to the nematicides being applied (Table 5).

\section{Discussion}

A diverse range of plant-parasitic nematodes are normally found on turfgrass (Smiley et al. 2005) and the results presented here show that this is also the case in Queensland. Interestingly, the most commonly occurring species were Paratrichodorus minor and Rotylenchulus brevicaudatus, which were both reported to be widespread in Queensland when described by Colbran $(1956,1962)$.

At least three plant-parasitic nematodes were generally found in diagnostic samples but in most cases, nematodes were not causing significant damage for the following reasons. First, the nematode counts in most samples were well below threshold levels utilised in Australia (Stirling 2008) and countries with a similar climate such as the United States (Buckley et al. 2010; Crow 2014). Second, the superintendents at most sports venues routinely monitor pests and diseases, and so many of the samples processed came from turf that was in reasonably good condition. Third, when the turf was in poor condition and nematode counts were above threshold levels, the problem was not necessarily due to nematodes because other soilborne pathogens, together with stress caused by factors such as unfavourable temperatures, compaction, low mowing heights, and inadequate inputs of water and nutrients, may have been contributing (Smiley et al. 2005). The genera most likely to be of concern in Queensland are Paratrichodorus, Xiphinema and Pratylenchus, as they sometimes occurred at population densities much greater than the damage threshold. Ring nematodes in the family Criconematidae may also have been causing problems in some situations. This slow-moving nematode is not extracted readily using the Baermann tray method, and so numbers are likely to be much higher than reported here.

The most important finding from the samples processed by two diagnostic services is that I. lolii, the most damaging nematode pest of turfgrass in Australia, was never detected. Although a formal survey was not undertaken, 744 diagnostic samples were processed and they were obtained from 160 locations in all regions of the state. As samples were obtained from a comprehensive range of locations and turfgrass uses, the results suggested that I. lolii does not occur in Queensland.

Nambiar et al. (2010) indicated that I. lolii was found at two sites in Queensland (later identified as Indooroopilly Golf Club and Weipa Bowls Club). We confirmed that the nematodes on herbarium slides labelled with those locations were I. lolii. However, the results of samples taken from both locations in 2014 suggested that the nematode was not present at either location. Also, information obtained from the superintendents of each club support that contention. First, the greens at both locations had remained in play from 2000 to 2014 but had never suffered the poor growth or decline symptoms usually observed when southern sting nematode is present. Second, a host plant was always available and nematicide treatments were not applied during that period, and so if I. lolii had been present, it should have survived. Third, in the years prior to 2000 , neither club obtained turf from an interstate site that may have been infested with I. lolii. Additionally, AGSCA checked its records and indicated that the wrong location may have been accidently put on the report that was sent to the Indooroopilly Golf Club in September 2000. Finally, I. lolii was not detected at Indooroopilly Golf Club in samples collected from six greens in June 2015.

The results obtained in 2014 and the comments above do not prove that the two Queensland locations purported to be infested with I. lolii are free of the nematode. Nevertheless, we would argue that they raise doubts about its presence. Thus, as mentioned later in this discussion, the sites should be re-sampled by biosecurity authorities to determine whether I. lolii is present.

Given the results discussed above, the decision to transfer potentially infested turf to the Gabba for the AFL Grand Final was a concern to the authors, as they were familiar with the nematode situation on turfgrass in Queensland. Those concerns were realised when I. lolii was found in turfgrass rolls that had been transferred from the MCG turf farm in Victoria. Again, it is not possible to be definitive, but this may have been the first introduction of I. lolii into Queensland. Thus, it mirrors the transfer of I. lolii to WA in the 1970s (Stirling et al. 2013) and is somewhat comparable to a situation in the United States where a closely related nematode (Belonolaimus longicaudatus) is thought to have been transferred from one of the south-eastern states to residential estates and golf courses in California (MundoOcampo et al. 1994; Cherry et al. 1997).

Although it is difficult to eradicate a nematode once it is introduced to a new area, the evidence available to date suggests that the action plan implemented to eliminate $I$. lolii from the Gabba was successful. In the 6 months after the imported turf was removed and the infested areas fumigated, multiple samples were collected from those areas and I. lolii was not detected. Also, the monitoring program on the oval failed to detect the nematode. However, these results are not definitive because it is difficult to detect very low populations of a particular nematode. For example, when a $500 \mathrm{~mL}$ sample is processed in a laboratory, there is only a $63 \%$ chance of detecting the nematode when there are 400 nematodes $/ \mathrm{m}^{2}$ in the upper $20 \mathrm{~cm}$ of the soil profile (Southey 1986). Thus, continual monitoring for several years will be required to confirm that the nematode has been eliminated. 
Given that I. lolii was not found in the soil adjacent to where the infested turf had been laid, it is unlikely that the nematode had moved onto the oval before the turf and surrounding soil was removed and the area fumigated. Nevertheless, a nematicide program for the whole oval was implemented, with the two nematicides registered for use on turf (abamectin and fluopyram) applied sequentially at recommended application rates. Although the results suggested that the nematicides may have reduced numbers of free-living nematodes and the increased numbers of $H$. dihystera, it is not clear whether they were entirely responsible for these effects, as there were seasonal changes in the proportion of couch and perennial rye in the sward during the monitoring period. The two grasses may not have been equally good hosts of $H$. dihystera while the free-living nematode community may have been affected by the seasonal changes in root biomass that would have occurred. Regardless of the reason for the results, reapplying the nematicides was not warranted because if $I$. lolii was present on the oval, the chemicals would not be effective enough to prevent the nematode from reappearing.

Experience in WA has shown that sparse turf cover, patchiness and poor surface integrity are often observed in community sports fields infested with I. lolii (Ruscoe et al. 2021). However, much greater management inputs are possible in major sports stadiums, and so it is not clear whether the nematode would be as destructive if it became established at a major sports venue such as the Gabba. A consultant at an infested stadium in Perth indicated that the effects of the nematode could be reduced to some extent by optimising the nutrition and irrigation program, applying a nematicide in spring, and using biostimulants, but such programs are expensive and require a high level of management. Installation of hybrid grass with its reticulated grid backing is also likely to be beneficial because it reduces the chances of players slipping on a patchy surface.

To conclude, the results of this study indicate that I. lolii either does not occur in Queensland or has a very limited distribution. The nematode was never found in diagnostic samples received from 160 sites located in all regions of the state; it was not detected at the two Queensland sites purported to be infested; and a program to eliminate a recent infestation at the Gabba appears to have been successful. Thus, we suggest that Queensland should be considered provisionally free of I. lolii. Biosecurity authorities and the turf industry therefore need to take steps to minimise the risk of the nematode being transferred into and within the state.

Biosecurity Queensland (the state government agency responsible for biosecurity) has a quite different point of view. When advised that I. lolii had been detected at the Gabba, the Manager (Policy, Incident Response and Preparedness) indicated that there was little point in taking action because I. lolii "already has a wide distribution in other states and territories; has been established for many years; could be easily spread through the movement of infested soil and plant material; and movement of turf or associated equipment or machinery may have been occurring from infested areas for many years".

As I. lolii is a serious pest of turfgrass and could potentially damage crops such as sugarcane, cereals, and maize (Stirling et al. 2013), we would argue that Queensland should establish a biosecurity program with four components: 1, inclusion of I. lolii on the Biosecurity Queensland website under 'Priority pests and diseases"; 2 , production of educational material that provides information on the pathogenicity of I. lolii and its distribution within Australia and explains how turf practitioners can minimise the risk of spreading the nematode to new locations; 3 , establishment of a long-term surveillance program to check whether I. lolii is present at the Gabba and other Queensland sites purported to be infested, and surveys turf farms and turfgrass sites that have never previously been sampled for nematodes; and 4, development of arrangements with private and governmentfunded nematology laboratories requiring them to notify Biosecurity Queensland if I. lolii is detected in diagnostic samples. If the above program, or something similar, is not enacted, the scenario in WA that was outlined in the introduction and described in detail by Ruscoe et al. (2021) is likely to be repeated.

Acknowledgements We thank Neil Wilson (Metagen), who used molecular methods to confirm the identity of some of the plantparasitic nematodes detected at the Gabba; and Peter Kirby (Indigo Specialty Products), who helped develop the action plan to eliminate I. lolii from the Gabba. However, David Sandurski, Grounds Manager at the Gabba, deserves a special mention because he implemented the action plan in its entirety, and was the main reason it appears to have been successful.

Authorship statement Graham Stirling assessed the sites purported to be infested with I. lolii, recovered sting nematode from the turf imported from Victoria, monitored nematode populations at the Gabba, and prepared the paper. Anne (Marcelle) Stirling and Lois Eden processed the diagnostic samples received by Biological Crop Protection and Eden Diagnostic Services, respectively.

\section{References}

Buckley RJ, Koppenhofer AM, Tirpak S (2010) An integrated approach to pest management in turfgrass: Nematodes. Rutgers University, New Jersey. Fact Sheet FS1014

Colbran RC (1956) Studies of plant and soil nematodes. 1. Two new species from Queensland. Qld J Agric Sci 13:123-126

Colbran RC (1962) Studies of plant and soil nematodes. 5. Four new species of Tylenchoidea from Queensland pineapple fields. Qld J Agric Sci 19:231-239

Cherry T, Szalanski AL, Todd TC, Powers TO (1997) The Internal Transcribed Spacer Region of Belonolaimus (Nemata: Belonolaimidae). J Nematol 29:23-29 
Crow WT (2014) Nematode management for golf courses in Florida. University of Florida ENY-008

Crow WT (2017) Nematode management in residential lawns. University of Florida ENY-006

McLeod R, Reay F, Smyth J (1994) Plant nematodes of Australia listed by plant and by genus. NSW Agriculture. ISBN 0731056116

Mundo-Ocampo M, Becker JO, Baldwin JG (1994) Occurrence of Belonolaimus longicaudatus on bermudagrass in the Coachella Valley. Plant Dis 78:529

Nambiar L, Quader M (2008) Plant-parasitic nematodes on Australian Turf. Abstracts, Fifth International Congress of Nematology, Brisbane, 331

Nambiar L, Quader M, Nobbs JM (2010) Morulaimus gigas (Nematoda: Belonolaiminae) in southern and eastern Australia. Aust Plant Dis Notes 5:39-41

Ruscoe PE, Stirling GR (2020) Southern sting nematode (Ibipora lolii), a serious pest of turf grasses in Australia. A review of what can be learnt from research on Belonolaimus longicaudatus, a closely related pest of turfgrass and many crops in the United States. Aust Plant Pathol 49:493-504

Ruscoe PE, Aitken EAB, Stirling GR (2021) Southern sting nematode (Ibipora lolii): its occurrence and population dynamics in Western Australia and an assessment of resistance and tolerance to the nematode in turf grasses. Aust Plant Pathol. https://doi.org/10. 1007/s13313-021-00805-0

Siviour TR, McLeod RW (1979) Redescription of Ibipora lolii (Siviour 1978) comb. N. (Nematoda: Belonolaimidae) with observations on its host range and pathogenicity. Nematologica 25:487-493
Southey JF (1986) Principles of sampling for nematodes. In Laboratory methods for work with plant and soil nematodes. Ministry of Agriculture Fisheries and Food, Reference Book 402:1-4

Smiley RW, Dernoeden PH, Clarke BB (2005) Compendium of turfgrass diseases (Third edition). Amer Phytopath Soc, Minnesota

Stirling GR (2008) Managing nematode pests on turfgrass. Aust Turfgrass Management 10(5):44-48

Stirling GR, Stirling AM, Giblin-Davis RM, Ye W, Porazinska DL, Nobbs JM, Johnston KJ (2013) Distribution of southern sting nematode, Ibipora lolii (Nematoda: Belonolaimidae), on turfgrass in Australia and its taxonomic relationship to other belonolaimids. Nematology 15:401-415

Whitehead AG, Hemming JR (1965) A comparison of some quantitative methods of extracting small vermiform nematodes from soil. Ann Appl Biol 55:25-38

Zeng Y, Ye W, Martin B, Martin M, Tredway L (2012) Diversity and occurrence of plant-parasitic nematodes associated with golf course turfgrasses in North and South Carolina, USA. J Nematol 44:337-347

Zeng Y, Ye W, Kerns J, Martin TL, S, Martin M, (2015) Molecular characterization and phylogenetic relationships of plant-parasitic nematodes associated with turfgrasses in North and South Carolina, United States. Plant Dis 99:982-993 